\title{
The Interactive Technology of Creative Workshops in Teaching Russian as a Foreign Language as a Tool for Developing Cross-Cultural Awareness of Students
}

\author{
Pavel Spisyak ${ }^{1}$ Natalia A. Bondarenko, ${ }^{2, *}$ \\ ${ }^{1}$ Private Slavic Gymnasium, Bratislava, Slovak Republic \\ ${ }^{2}$ Department of International and Regional Relation, The Leo Tolstoy Institute of Language and Culture, \\ Moscow, Russia \\ *Corresponding author. Email: b_natalia@mail.ru
}

\begin{abstract}
Cross-cultural awareness is one of the key competencies of a student as it forms the foundation for interethnic communication. An effective tool for developing this competence in students is the introduction of the interactive workshop technology in class. The article presents a lesson of Russian as a foreign language designed with the application of the creative workshop technology. While completing a series of creative tasks, students expand their vocabulary on the topic of Art and Theatre, and learn about the objects of the socio-cultural environment of Russia and Italy.
\end{abstract}

Keywords: Russian as a foreign language, interactive technologies, cross-cultural competence, creative task, vocabulary, theatre, P. Gonzaga, N.A. Benois

\section{INTRODUCTION}

In the era of globalization, cross-cultural communication and mutual understanding between representatives of different cultures are becoming the basis for social development. Intercultural communication parties interact with other, often dissimilar, ones. However, the main reasons for such contacts to fail lie behind the obvious; they imply different attitudes to the world and other people. The major obstacle to solving this issue is that students tend to perceive other cultures through the prism of their own one (meanwhile, another culture can motivate students and encourage reflection). [1] Therefore, effective intercultural communication cannot establish by itself; students are required to learn it, as well as to form and develop cross-cultural awareness. It should be emphasized that cross-cultural awareness is a systemic construct that combines knowledge, understanding and respect for languages, traditions, and psychology of an ethnic group. [2]

\section{THE APPLICATION OF INTERACTIVE TECHNOLOGIES IN TEACHING RUSSIAN AS A FOREIGN LANGUAGE}

Cross-cultural awareness is an element of crosscultural competence, which is referred to as a complex aspect of science about language and the development of the linguistic persona paradigm in the context of multicultural communication and interrelation of language and culture.

The issues of the development of cross-cultural awareness have been studied and discussed in the works by many scholars (e.g. A.T. Kolosovskaya, R. Hanvey, A.G. Lapshin, etc.).

According to R. Hanvey, the American scientist, cross-cultural awareness is the consciously considered perception of a culture, its people, and differences between cultures that implies:

- readiness to understand cultural differences, provided an individual possesses such qualities as empathy, tolerance, etc.;

- respectful and tolerant attitude to different habits, views, and norms [3]. 
Defining cross-cultural awareness, A.G. Lapshin stresses that this phenomenon should be understood as "the acknowledgement of the divergence of ideas, customs and cultural traditions inherent in different peoples, and the ability to observe the common and the different between cultures and to get an outsider's perspective about one's own traditions." [4] V.T. Roshchupkin considers cross-cultural awareness as "the ability of an individual to acknowledge another culture, its content and forms and to participate in joint cultural activity that encourages their personal enhancement." [5]

Thus, by cross-cultural awareness the authors of the present article mean a quality of an individual which is formed through perceiving a foreign culture, its traditions and history, and a person's communication skills which they display in intercultural communication.

It is essential to highlight that the foundation for understanding a foreign culture is the degree of students' awareness of the differences between their own and foreign cultures. This issue can be effectively addressed with the help of interactive technologies (I.V. Bimurzina, V.G. Roshchupkin, N.G. Markova, etc.). [6]

Interactive technologies imply a teacher-student dialogue. This interaction is based on the understanding of social interaction in interpersonal communication, the key feature of which is the ability of a person to take another person's role and to imagine how they can be perceived by another communication party. [7]

When applying interactive technologies, almost all students get involved in the learning process. In such interactive learning environments, students have the opportunity to understand and reflect on what they are learning and doing, what they know and think.

\section{WORKSHOPS AS AN INNOVATIVE FORM OF LESSON ORGANIZATION}

One of the well-developed interactive technologies is the pedagogical technology of creative workshops. Its purpose is not only to pass along knowledge and information, but also to teach a certain way of working.

The theoretical basis for the development and implementation of the creative workshop technology has been laid by the philosophical and pedagogical ideas of the French Group for New Education (GFEN), which were established in France in the first quarter of the 20th century and spread in a number of countries in the 1980-90s. The first people to have introduced the creative workshop technology in Russia were teachers in St.
Petersburg. The technology has become widely applied since then.

A workshop is an unusual form of lesson organization. At each stage of such a lesson, when completing assignments, students are free to choose the level of difficulty, the means of achieving goals, and the ways to present the result of work, etc. It is a developmental space created by a teacher-master that allows students to acquire new knowledge in a collective search. A significant feature of the technology is a dialogue: firstly, there is an exchange of opinions, knowledge, and creative findings between the participants; secondly, there is an exchange between each student's experience on the one side, and a scientist, artist, cultural phenomenon, or event on the other side; and thirdly, each student enters into a dialogue with themselves. It is the result of students comparing their educational products with those of their group mates, as well as with the humanity's remarkable achievements recorded in textbooks and other sources. [8]

The result of a creative workshop is not only real knowledge or skill obtained, but most importantly the search for and discovery of the truth and creative production. It is due to this comparison that an individual's views about facts, processes and phenomena are formed (the content of education), a student's subjective experience is broadened, their individual knowledge, skills and abilities are improved, and attitudes and feelings are developed.

The algorithm of the workshop includes several stages: at the beginning, students deal with a problem situation (inductor) which stimulates their interest in the subject matter. This, in fact, is an appeal to the students' experience and their figurative thinking (a word, object, or memory can act as an inductor). There are several requirements for this task to be introduced: making use of everyone's personal experience (as it has been said above), and giving students a choice, which will motivate them.

Creation takes place at the deconstruction and reconstruction stages. The presentation of the created product takes place at the stage of socialization, when students can compare their results, and evaluate each other's ideas and hypotheses. However, the key task at this stage is not so much to evaluate the work of another person, but to self-evaluate and self-correct.

At the next stage, new information is addressed, a creative product is adjusted or a new one is created. Divergent viewpoints, clashes of interest and the variability of possible solutions are necessary tools for getting students closer to doing a creative task. 
At the pattern interrupt stage (insight stage), which is the culmination of the creative process, students get insight into the subject matter, which logically leads to a new information request. It should be noted that the pattern interrupt is an essential stage of a creative workshop, when students are given a paradoxical task. Dealing with the task, students are stuck in a conundrum, they try to resolve it and get insight, as a result.

Insights are different for different students. If in traditional teaching the knowledge is typically given to students, in a creative workshops it is independently discovered by students themselves, on their own or in group work. Performing such creative tasks and searching for answers provides a balance between the collective work and individual knowledge acquisition and contributes to the development of students' creative activity through group interaction and learning. The final stage of a workshop is reflection.

It is important to mention that with the application of the workshop technology, the process of knowledge acquisition has the usual steps: perception, comprehension, understanding, consolidation, application and generalization. However, it is student-cantered: at each stage of a lesson, tasks take into account students' motives and needs, focus on finding new meanings behind cognitive activity, and aim at sharing new knowledge with others, not only gaining it.

It is understood that the application of interactive technologies in teaching Russian as a foreign language allows expanding knowledge, deepening understanding and teaching students to be respectful of others, which is exactly what lies beneath a student's cross-cultural awareness.

\section{THE ARTISTS PIETRO GONZAGA (1751-1831, ITALY) AND NICOLA BENOIS (1901-1988, RUSSIA)}

The representatives of Italian culture, architects, singers, artists, musicians and composers, had a tremendous influence on the development of styles and trends in the Baroque era. Slovak students are thoroughly familiar with the architectural gems of Italian masters in Bratislava, Košice, Trnava and other cities of Slovakia.

What united the two artists and set designers, $\mathrm{P}$. Gonzaga and N.A Benois, was theatre in Italy and Russia. P. Gonzaga was born in Italy, but spent all his life in Russia, while N.A Benois, born in the Russian Empire, achieved fame and success in Italy.

Back in 1817, in Moscow, the celebrations with the participation of Emperor Alexander I on the occasion of the fifth anniversary of the victory over Napoleon were coming up. For this celebration,
Prince Yusupov decided to arrange a theatre hall in his estate: he decided to get the arena building in the western part of the landscape park fully reconstructed according to the design of $P$. Gonzaga, the invited architect from Italy, and his son Paolo.

The theatre was made of wood on a stone foundation and was constructed by the cartel of Osip Ivanov. By mid-1818, the theatre at the Arkhangelskoye Estate acquired its modern day appearance. The theatre was suitable for any kind of performances - drama, opera or ballet, but it was primarily expected to stage the performances of skilful sets.

It is known that P. Gonzaga made a front curtain and 16 set designs for the theatre. Visionary landscapes, interior designs, perspective colonnades and temples created a new reality and represented the artist's idea of the 'music for the eyes'. Four of the sets, Temple, Tavern, Prison, and Marble Gallery, and the picturesque front curtain have survived up to the present day.

Almost the entire original ensemble of sets designed by P. Gonzaga was in watercolours made in the 1820 s by the artists then working in the estate. However, Yusupov did not manage to present the entire work as planned; according to those present in the theatre, the sets were only changed three times, which Alexander I found disappointing.

Later, a significant part of the art treasures of the Arkhangelskoye Estate was transported to St. Petersburg by the heirs of Prince Yusupov. P. Gonzaga spent his entire life in Russia, and his buildings in the Arkhangelskoye Estate and Pavlovsk still gratify visitors.

In the 1920s, the Russian artist Nikola Benois moved to Milan, where he made his artistic debut at La Scala in 1925-1926. The invitation by La Scala had a major impact on the life of the entire Benois family. The young artist made sketches for ballets and costumes for Khovanshchina by $M$. Mussorgsky, which were highly appreciated by Arturo Toscanini. The success of this performance was a turning point in N. Benois's career. He got an instantaneous response from the best European theatres - the artist was ordered sets for Russian Performances - M. Mussorgsky's opera Boris Godunov for La Scala, The Fair at Sorochyntsi for the Berlin Opera, and The Tale of Tsar Saltan by N. A. Rimsky-Korsakov for the Colon Theatre in Buenos Aires. Since 1927, he settled in Milan and became a full-time artist at La Scala. The success in Milan was followed by the invitation to the Royal Opera of Rome. Thus, being twenty-six years old, Nicola Benois was a chief artist in two great Italian theatres at once. 
Learning about the artists belonging to Russia and Italy allows students to analyse the deep connections between the two countries, whose cultures are woven into the European context. Meanwhile, students get an opportunity to understand a foreign culture and integrate into it, which, in fact, is the goal of the development of cross-cultural awareness.

\section{THE WORKSHOP 'P. GONZAGA (1751- 1831) AND N.A BENOIS (1901-1988): THE ARTISTS' DIALOGUE}

When designing the lesson plan of the workshop under consideration, the authors of the article used the materials from course books on language skills development. [6] In the second part of the course book 'Russia - Italy: a dialogue of cultures' (a guide on reading and speech development for Italian students of humanities), a reader finds the information about the Russian artist N.A Benois (1911-1988), who worked at La Scala from 1937 to 1970 and created sets and costumes for 126 performances.

The workshop is aimed at Advanced learners of Russian as a foreign language.

The work in the workshop is preceded by substantial preparation: watching a documentary about the Arkhangelskoye Estate (Moscow region), the place of P. Gonzaga's theatre, and Pavlovsk (St. Petersburg), reading the text 'Russian Estates' and learning vocabulary items on the topic Russian Estates (e.g. собственность, владелец, гнездо, прогулка, круг общения, знатность происхождения, высший свет, etc.). In addition, students choose an act from a play by a Slovak playwright of the Baroque era to be staged in class.

The aim of the workshop is developing the skill of reading for specific information, improving speaking skills, using key vocabulary and expressions in sentences of various types, and developing cross-cultural awareness of students.

At the first stage (induction), a problem situation is created, which leads to new knowledge about the subject (photos of the architectural monuments built by Italian architects, in Bratislava, Moscow and St. Petersburg. Working individually and in a team, students come to the idea of the masters from Italy who were in demand both in Russia and Slovakia.

At the next stage (deconstruction), each group is given a task (Types of fine arts, Restore the text, Replace the words of the native language (Slovak) with their Russian equivalents and put them in the right case, Make a dialogue). [7]

Having presented the results of group work, students make dialogues on the topic Invitation to the Theatre using the following cards with vocabulary and expressions:

Card 1: Приглашение в театр (Invitation to the Theatre)

Разрешите (позвольте) пригласить вас в театр (Let me invite you to the theatre.)

Как вы посмотрите на то, чтобы ...пойти (отправиться) в театр? (How about going to the theatre?)

Не пойти ли нам в театр? (Why don't we go to the theatre?)

Не хотите ли вы составить мне компанию? (Would you like to keep me company to the theatre?)

Сходим в театр! (Let's go to the theatre!)

Положительные ответы (Positive answers):

Это неплохая мысль (That is a good idea!)

Неплохо бы, мне бы очень хотелось (That would be great!)

Это вполне меня устраивает (I agree.)

Не возражаю, пойдем (Let's go!)

Card 2: Приглашение в театр (Invitation to the Theatre)

Разрешите (позвольте) пригласить вас в театр. (Let me invite you to the theatre.)

Как вы посмотрите на то, чтобы ...пойти (отправиться) в театр? (How about going to the theatre?)

Не пойти ли нам в театр? (Why don't we go to the theatre?)

Не хотите ли вы составить мне компанию? (Would you like to keep me company to the theatre?)

Сходим в театр! (Let's go to the theatre!)

Отрицательные ответы (Negative answers):

Боюсь, что не смогу (I am afraid, I can't make it.)

Очень сожалею, что не смогу (I am sorry, but I can't make it.)

У меня все дни заняты (I am busy all days.)

Неплохо, но вряд ли смогу. (That is a good idea, but I am not sure I can make it.)

The next task is revision and learning about new jobs engaged in the creation of a performance. 
Task for Group 1: Students give definition to the word 'сиенография' (set design) using the given words in the correct case. Students draw a building of the theatre where the performance will take place.

Words: Вид, творчество, оформление, спектакль, изобразительно- пластический образ, сценография, занимающийся, его, существующего, время, пространство, в.

(Set design is a creative activity aimed at crafting stage environments for a performance and creating its pictorial and sculptural image in certain stage time and space.)

Task for Group 2: Students select pictures depicting the things that surround actors on stage and create costume designs.

(In theatre performances, the art of set design refers to everything that surrounds actors (sets), everything they deal with (material objects) and everything they put on (costumes, stage make-up, masks, etc.) As expressive means, set design can use objects created by nature, everyday life objects and results of artists' creative activity (from masks and costumes to painting, graphics, acting space and light, etc.).

Task for Group 3: Creating design sets for a play in the style of $\mathrm{P}$. Gonzaga ('music for the eyes').

Task for Group 4: Creating design sets for a play using the sets of N.A Benois.

At the pattern interrupt stage, students demonstrate the results of their work and show an extract from a play.

Task for all groups: Students recreate a speech situation and produce speech utterances based on what they have seen using the following vocabulary:

Режиссура, постановка, оформление спектакля (Directing, staging, set design)

\section{Спектакль}

интересный/запоминающийся/неинтерес ный, скучный (The performance is interesting/ remarkable/ boring.)

Оформление (декорации) выполнено(ы) с мастерством (Sets are done with consummate skill)

\section{Реакция зрителей (Audience response)}

Следить (с интересом) за игрой, за ходом развития действия, не спускать глаз (Watch with particular interest, be glued)

Отзываться с восторгом (Praise highly)
Получать огромное удовольствие (Take great pleasure in).

Reflection Stage: Each student creates a drawing or painting to reflect and summarize what they have experienced in the workshop.

\section{CONCLUSION}

The application of interactive technologies (the workshop technology in particular) allows students not only to address their personal experience, do problem-oriented tasks, and listen to each other, but also to improve their knowledge. During the creative workshop 'P. Gonzaga and N.A Benois: the artists' dialogue' (for the Advanced level of language competence) students complete a series of creative tasks, expand their vocabulary on the topic of Art and Theatre and learn about the objects of sociocultural environment (e.g. the Theatre by P. Gonzaga in Arkhangelskoye Estate, the Pavlovsk Park; the sets by N.A. Benois for the performances at La Scala, the Bolshoi Theatre, etc.). At the end of the workshop students reach a conclusion that "culture is able to exist and develop only in dialogue with other cultures" (M.M. Bakhtin). The application of interactive technologies allows expanding knowledge, deepening understanding and teaching students to be respectful of others, which is exactly what lies beneath a student's crosscultural awareness.

\section{References}

[1] Roshchupkin V.G. Cross-cultural awareness of a future teacher: diagnostics, formation. Moscow. Publishing house of the Moscow psychological and social institute; Voronezh: Publishing house NPO 'MODEK', 2006. p. 110.

[2] Markova N.G. Cross-cultural awareness as an indicator of interethnic understanding. Bulletin of the Herzen State Pedagogical University of Russia. 2008. Pp.159-162.

[3] Hanvey R. An Attainable Global Perspective. Russian translation by Ya.M. Kolker et al. Ryazan. 1994. 69 p.

[4] Lapshin A.G. International cooperation in the field of humanitarian education: the prospect of cross-cultural awareness. Cross-cultural dialogue: comparative studies in pedagogy and psychology. Vladimir. 1999. $47 \mathrm{p}$.

[5] Roshchupkin V.G. Formation of cross-cultural awareness of students of a pedagogical university. Author's abstract. Samara. 2009. 63 p.

[6] Kharlovy N.M. The use of interactive technologies in teaching Russian as a foreign language. Bulletin of the Shadrinsk State Pedagogical University, 2017; L.R. Baktrova. Interactive methods and techniques of conducting lessons of Russian as a foreign language. Issues of Theory and Practice. Tambov. 2017. No. 7 (73), Vol.1. Pp. 177-179, etc.

[7] Passov E.I. The concept of communicative foreign language education: a methodological guide for Russianists. Moscow. 2007. P. 145.

[8] Selevko G.K. Educational technologies based on information and communication tools. Moscow. Research Institute of School Technologies. 2005. 208 p 
[9] Russia - Italy: a dialogue of cultures. A guide on reading and speech development for Italian students of humanities. Ed. by S.K. Miloslavskaya. 2011. 288p. The authors of the 1st part (A1, A2.) - L. Bonchani, R. Romagnoli; the authors of the 2nd part - Yu.V. Nikolaeva, S.L. Nistratova, E.G. Rostova.

[10] https://learningapps.org/watch?v=pisay4p0320,

https://learningapps.org/watch?v=p4jksaenk20,

https://learningapps.org/watch?v=pwmroy 72320 